\title{
THE DISTRIBUTION, ECOLOGY AND CONSERVATION NEEDS OF COLOBANTHUS CURTISIAE WEST
}

\author{
Louise Gilfedder and J.B. Kirkpatrick
}

(with four tables and two text-figures)

Gilfepder, L. \& Kirkpatrick, J.B., 1996 (30:vi): The distribution, ecology and conservation needs of Colobanthus curtisiae West. Pap. Proc. R. Soc. Tasm. 130(1): 25-30. https://doi.org/10.26749/rstpp.130.1.25 ISSN 0080-4703. Department of Geography \& Environmental Studies, University of Tasmania, GPO Box 252C, Hobart, Australia 7001 QBK and formerly LG), LG now Parks and Wildlife Division, DELM, GPO Box 44A, Hobart, Tasmania, Australia 7001 (LG).

Colobanthus curtisiae is known from only 16 populations, most of less than 100 individuals, in the Midlands and Northeastern Highlands of Tasmania. The species occurs in phytosociologically diverse grassy vegetation from $160 \mathrm{~m}$ to $1300 \mathrm{~m}$ above sea level. This vegetation is rich in herbs and introduced plants, and has much bare ground. C. curtisiae germinants were observed in two grazed sets of permanent quadrats but were absent from ungrazed plots. The species is vulnerable to pasture improvement and land clearance and to the lack of disturbances which create bare ground. It requires protection and appropriare management in the lowland part of its range.

Key Words: Colobanthus curtisiae, endangered plant, germination, grazing, threatened plant, Tasmania.

\section{INTRODUCTION}

The dicotyledonous perennial herb Colobanthus curtisiae West was discovered by Rod Fensham in 1985 at Campbell Town Cemetery. This population was eliminated a week later in a cleanup. Several years later populations were located on a roadside at Tunbridge and from Ben Lomond National Park (Davies \& Davies 1989), and the species was subsequently described from this material (West 1991). C. curtisiae is a Tasmanian endemic small rosette herb in the Caryophyllaceae. It resembles $C$. apetala but differs in its longer and narrower sepals and its colliculate testa patterning (West 1991). It is a grassland and grassy woodland plant. These ecosystems have suffered severe habitat destruction or degradation since the European invasion (Fensham \& Kirkpatrick 1989, Fensham 1989, Gilfedder \& Kirkpatrick 1995).

C. curtisiae is listed as endangered on both the national and state levels (Endangered Flora Network 1993; Flora Advisory Committee 1994).

This paper maps the known distribution of the species, places it in its environmental and phytosociological context, describes the germination behaviour of one lowland population, reports the responses of the species to different grazing regimes in three lowland populations and draws conclusions on the conservation needs of the species.

\section{METHODS}

\section{Distribution, Phytosociology and Environment}

Searches were made for additional populations of the species in apparently suitable habitats, the search pattern being modified as newly discovered populations revealed further aspects of its preferences. In some cases, additional populations were found in the course of other investigations. Floristic and site data were recorded for each located population. Quadrats measuring $1 \times 10 \mathrm{~m}$ were subjectively placed in the least disturbed vegetation in which $C$. curtisiae occurred at each site, and all observable vascular plant taxa within the quadrat noted. Species nomenclature follows
Buchanan (1995). Altitude, surface geology, soil surface $\mathrm{pH}$ (using a CSIRO soil-testing kit) and soil type were noted or measured in the field. The slope and aspect of each site were determined using a clinometer and compass respectively. Climatic data were derived for each site using the Bioclimatic Prediction System (Busby 1988).

The polythetic divisive technique TWINSPAN (twoway indicator species analysis) (Hill 1979) was used to obtain a sorted table. This table was then manually resorted to improve its organisation, with the aim of placing quadrats with similar species composition close together and species with similar quadrat distributions close together. This was necessary as TWINSPAN is a poor sorter of species and inverts the quadrat sequences on division.

The percentage frequencies of other vascular plant taxa in quadrats with $C$. curtisiae were determined, as were the percentage frequencies for all taxa occurring in the rest of the grassy ecosystem data set (Kirkpatrick et al. 1988). A list was made of those species that occurred in $10 \%$ or more of quadrats in either of the databases, the list being separated into those occurring more frequently with $C$. curtisiae and those occurring more frequently without $C$. curtisiae. These species were then classified into lifeform groups (shrub or tree; grass, graminoid, geophyte; herbs) and two origin groups (Tasmanian native; other).

\section{Population Monitoring}

Population numbers were monitored from 1990-94 at three low altitude locations (table 1) with different grazing management regimes. At Tunbridge, on a roadside which is used on a regular basis as a stock route and where the population numbers less than 50 individuals, seven permanent plots $(0.5 \times 0.5 \mathrm{~m})$ were established within the population. At the South Esk River site, which is a heavily grazed native pasture with \pm 1000 C. curtisiae individuals, two transect lines were placed through the population, and 23 contiguous quadrats measuring $0.5 \times 0.5 \mathrm{~m}$ were monitored. A third population ( $<100$ individuals) was monitored at a site on a Holocene lunette west of Campbell Town. This site had been previously grazed but stock had been excluded 
TABLE 1

Localities with Colobanthus curtisiae

\begin{tabular}{|c|c|c|c|c|c|}
\hline Locality & $\begin{array}{l}\text { Altitude } \\
(\mathrm{m})\end{array}$ & Geology & Tenure & $\begin{array}{l}\text { Species } \\
\text { richness }\end{array}$ & $\begin{array}{l}\text { Dominant } \\
\text { tree species }\end{array}$ \\
\hline Ben Lomond & 1300 & sandstone & national park & 20 & above treeline \\
\hline Buffalo Brook & 300 & sand & private & 19 & Acacia mearnsii \\
\hline Campbell Town $1^{*}$ & 160 & sand & private & n.a. & Eucalyptus pauciflora \\
\hline Campbell Town 2 & 310 & dolerite & private & 26 & E. viminalis \\
\hline Campbell Town 3 & 200 & basalt & cemetery & extinct & E. pauciflora \\
\hline Fingal Tier & 700 & dolerite & state forest & 20 & E. amygdalina \\
\hline Lagoon of Islands & 760 & dolerite & $\mathrm{HEC}$ & 21 & E. obliqua \\
\hline Andover & 430 & sandstone & private & 28 & E. pauciflora \\
\hline Near Lagoon & 240 & sand & private & 17 & A. dealbata \\
\hline Ouse River & 400 & sandstone & private & 10 & E. dalrympleana \\
\hline Shannon River 2 & 360 & sandstone & private & 14 & E. viminalis \\
\hline South Esk River* & $180-240$ & dolerite & private & 27 & E. pauciflora \\
\hline Shannon River 1 & 620 & dolerite & private & 10 & E. rubida \\
\hline Swanston & 240 & sandstone & private & 15 & E. pauciflora \\
\hline Tunbridge* & 240 & dolerite & roadside & 24 & E. rodwayi \\
\hline Valleyfield & n.a. & n.a. & private & n.a. & n.a. \\
\hline Woodbury & n.a. & sandscone & private & n.a & E. viminalis \\
\hline
\end{tabular}

n.a. = not available

* Sites where the species was monitored from 1990-94.

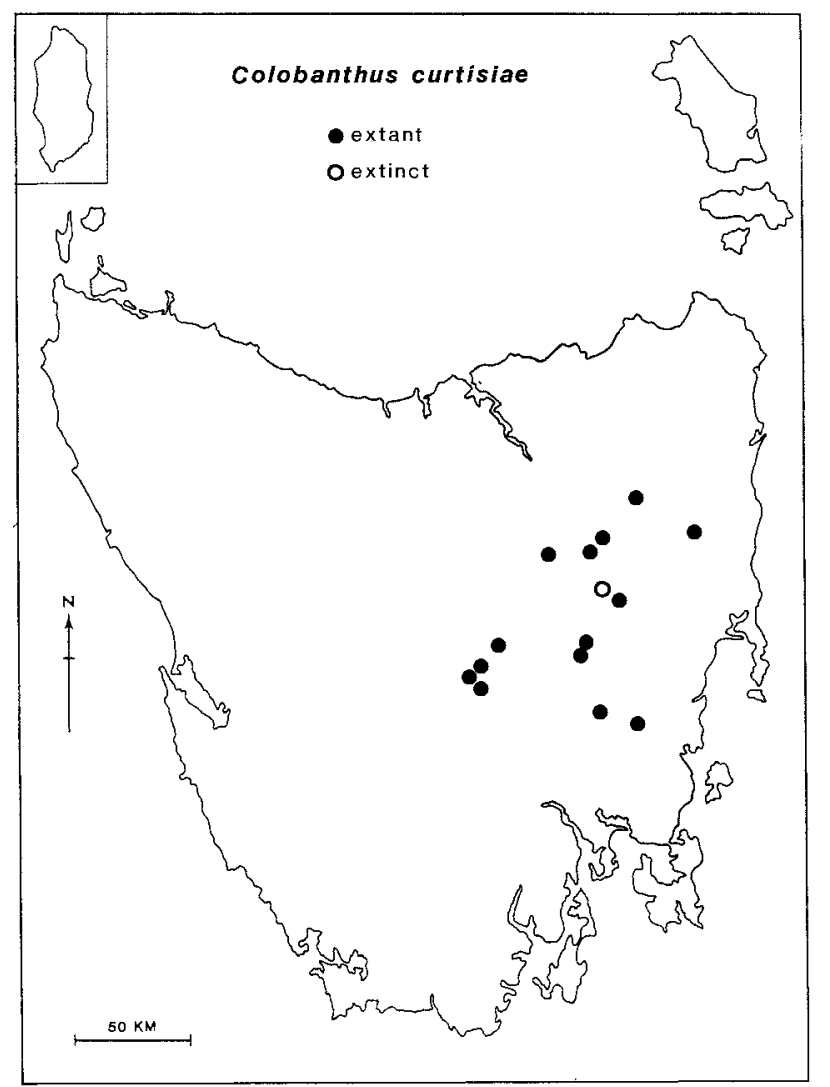

FIG. 1- Extant and past localities for Colobanthus curtiseae for several years. A $5 \mathrm{~m}$ transect line was placed through the population of $C$. curtisiae and 11 contiguous quadrats measuring $0.4 \times 0.4 \mathrm{~m}$ were placed at $0.5 \mathrm{~m}$ intervals. The number of adult individuals, the number of recent germinants, the number of flowers per plant, and the BraunBlanquer cover scale (Mueller-Dombois \& Ellenberg 1974) for grasses, herbs, exotic plants and bare ground were recorded at yearly intervals. Data were converted to density per square metre.

\section{Germination}

Germination tests were conducted on seeds of $C$. curtisiae collected from the South Esk site on 12 February 1991. The seed was stored in bags at ambient room temperature. Germination tests were carried out by placing the seed on moist double layers of filter paper (Whatman No. 1) in $90 \mathrm{~mm}$ Petri dishes on 4 June 1991 . For each trial there were five replicates of twenty seeds placed in randomised blocks. The seeds were checked twice daily and watered with distilled water when necessary, ensuring that the filter paper was maintained in a moist but not wet condition. The seed was germinated in an incubator in dark conditions, with the seeds being exposed to light when watered. Four temperatures were used for each replicate: $5^{\circ}, 10^{\circ}, 15^{\circ}$ and $20^{\circ} \mathrm{C}$. There was no pre-treatment.

\section{RESULTS}

\section{Distribution, Phytosociology and Environment}

C. curtisiae was found at 14 addirional sites, and survives at two of the previously known sites (fig. 1, table 1). It occurs on gentle slopes between 160 and $1300 \mathrm{~m}($ median $=310 \mathrm{~m})$ in elevation in inland Tasmania. Mean annual rainfall varies 
from $530 \mathrm{~mm}$ in the lowland Midlands area to more than $1400 \mathrm{~mm}$ on Ben Lomond, with a median of $607 \mathrm{~mm}$. The mean temperature of the warmest monch varies from $10.5^{\circ}$ to $16.1^{\circ} \mathrm{C}$, with a median of $15.1^{\circ} \mathrm{C}$. The mean temperature of the coolest month varies from $1.6^{\circ}$ to $6.5^{\circ} \mathrm{C}$. Soils are predominantly sandy loams derived from sandstone or Holocene sands, but the species also occurs on clay loams derived from dolerite and basalt. Rock cover is absent at most sites. The median soil pH is 6 (range 4.5-8.5).

The median native species richness was $19 / 10 \mathrm{~m}^{2}$ (range $7-32)$. The median exotic species richness was $6 / 10 \mathrm{~m}^{2}$ (range $0-11$ ). The median of Tasmanian endemic species richness was 1 (range $1-7$ ).

The native species occurring in more than $40 \%$ of the quadrats with $C$. curtisiae were, in order from high to low co-occurrence: Scleranthus biflorus, Carex breviculmis, Oxalis perennans, Acaena novae-zelandiae and Poa labillardierei. Herbs and introduced taxa proved to have higher frequencies in the $C$. curtisiae data set than in the grasslands and grassy woodlands data set (table 2). The reverse pertained for grasses (table 2).

Bray-Curtis distance values (Minchin 1990) between quadrats varied from a high of 0.9070 berween a lowland and an alpine quadrat to 0.2143 between two lowland quadrats. At least four groups of quadrats can be perceived in the sorted table (table 3), although the variation is more or less continuous. Group I is best characterised by the relatively faithful taxa in species group $A$. The most constant of these taxa are Wablenbergia spp., Danthonia carphoides and Plantago varia. Group II has many highly faithful taxa, these being in species group C, but none of these is highly constant. Its constant species are Aira caryophyllea, Oxalis perennans, Scleranthus biflorus, Acaena novae-zelandiae and Poa labillardierei. The relatively faithful species in quadrat group III are in species group K. Of these, only Elymus scabrus has a high degree of constancy. Other constant species are Poa labillardierei, Acetosella vulgaris, Scleranthus biflorus and Aira caryophyllea. The Ben Lomond quadrats form group IV, which is best characterised by the highly faithful and constant Plantago paradoxa and Senecio pectinatus.

\section{Population Monitoring}

Between 1990 and 1994, C. curtisiae increased in density in the heavily grazed plots (South Esk), decreased in density in the intermittently grazed plots (Tunbridge) and changed little in the ungrazed plots (Campbell Town) (table 4). Successful establishment of germinants was observed from 1990-94 in the heavily grazed plots (table 4), with the number of new germinants being higher in 1994 than 1990 . Germinants were also observed in the occasionally grazed plors, but only in 1994. No germinants were observed in the ungrazed plots. The density of flowers increased between 1990 and 1994 in the heavily grazed plots, while decreasing in the other plots. In 1994, the heavily grazed plots had a higher percentage cover of bare ground, herbaceous plants and exotic species than the other sites (table 4).

\section{Germination}

High germination levels of $C$. curtisiae were achieved at $5^{\circ} \mathrm{C}$ (73\% of seed) and $10^{\circ} \mathrm{C}(69 \%)$ (figure 2 ), with only $2 \%$ of seeds germinating at $15^{\circ} \mathrm{C}$ and none at $20^{\circ} \mathrm{C}$. Germination at $5^{\circ} \mathrm{C}$ was delayed until after day 30 . The seed of C. curtisiae was observed in profusion in an ants nest at the South Esk site. Fifty to 100 seeds can be obtained per inflorescence.

\section{DISCUSSION}

C. curtisiae has a wide phytosociological and environmental range, suggesting that the cause of its rarity is not the lack of substantial areas of suitable physical environment, at least before the European invasion. Our data from one lowland site indicate that $C$. curtisiae is an easily germinated species with a large seed output, suggesting that reproducrive problems are also unlikely to be a cause of its rarity. Our permanent plot observations suggest that it is able to survive and successfully regenerate with a level of stock grazing which renders other threatened taxa of grassy ecosystems, such as Lepidium hyssopifolium and Barbarea australis, locally

TABLE 2

Composition of lifeform groups associated with Colobanthus curtiseae*

\begin{tabular}{lcccc}
\hline Lifeform group & $\begin{array}{c}\text { More common with } \\
\text { Observed }\end{array}$ & $\begin{array}{c}\text { Curtiseae } \\
\text { Expected }\end{array}$ & $\begin{array}{c}\text { Less common with C. curtiseae } \\
\text { Observed } \\
\text { Expected }\end{array}$ \\
\hline Trees and Shrubs & 5 & 7 & 10 & 8 \\
Grasses & 8 & 12 & 18 & 14 \\
Graminoids & 5 & 6 & 7 & 6 \\
Geophytes & 2 & 3 & 4 & 3 \\
Herbs & 37 & 29 & 23 & 31 \\
Introduced species & 17 & 10 & 4 & 11 \\
\hline
\end{tabular}

\footnotetext{
* The number of species in different lifeform and origin groups that are more frequent in vegetation with C. curtiseae than in Tasmanian grasslands and grassy woodlands and vice-versa. Only species occurring in more than $10 \%$ of the quadrats in at least one of the data sers are included.

$\dagger$ As in Chi-squared.
} 
TABLE 3

Sorted table for quadrats with Colobanthus curtisiae

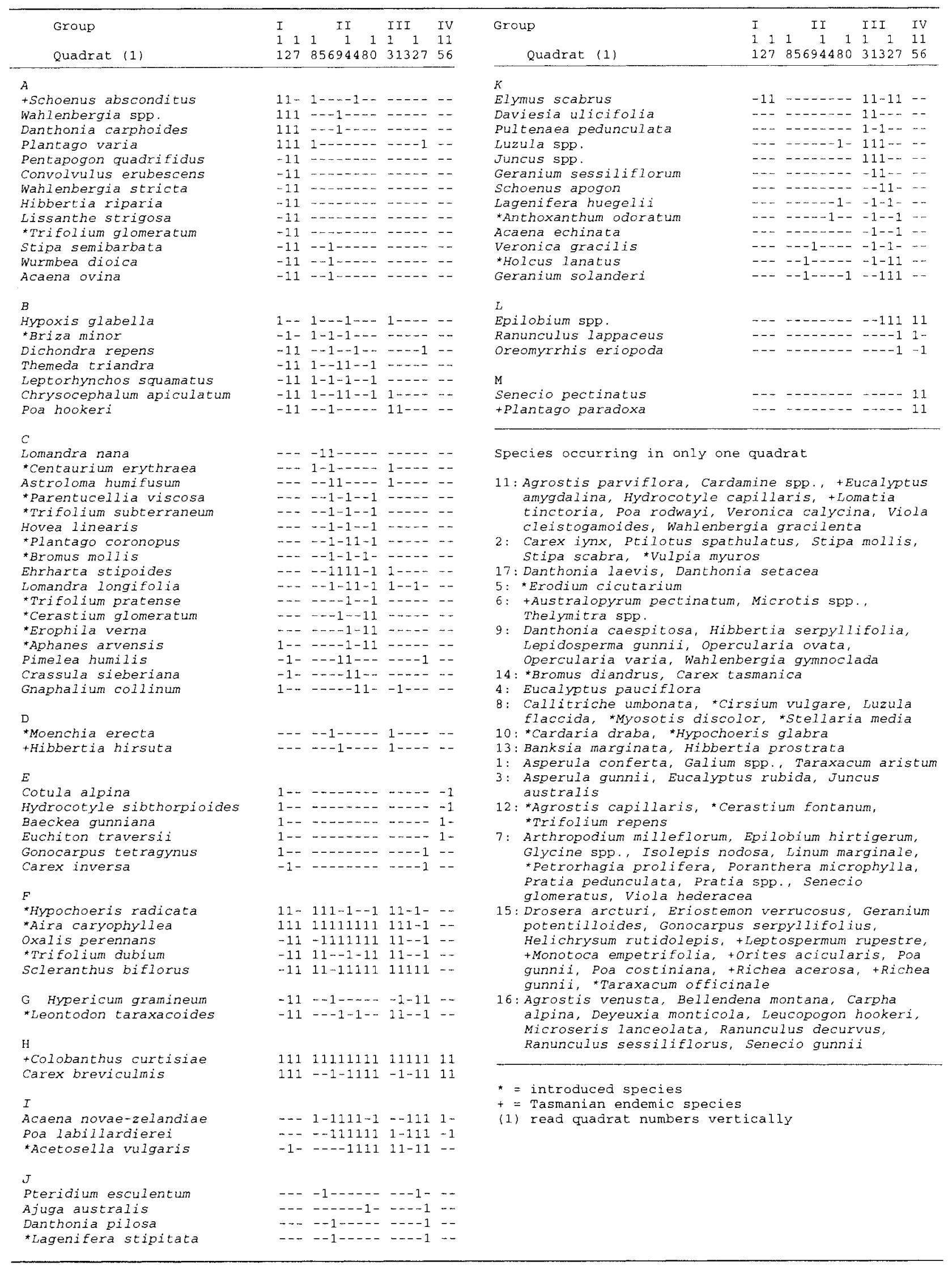


TABLE 4

Mean and standard error of Colobanthus curtisiae and ground cover types per square metre under different management regimes

\begin{tabular}{|c|c|c|}
\hline Location & 1990 & 1994 \\
\hline \multicolumn{3}{|l|}{ C. curtisiae/ $\mathrm{m}^{2}$} \\
\hline South Esk R. & $176.9 \pm 42.2$ & $278.0 \pm 59.8$ \\
\hline Tunbridge & $143.8 \pm 86.9$ & $38.4 \pm 11.6$ \\
\hline \multicolumn{3}{|l|}{ new germinants $/ \mathrm{m}^{2}$} \\
\hline South Esk R. & $2.45 \pm 1.09$ & $8.70 \pm 1.79$ \\
\hline Tunbridge & 0 & $2.68 \pm 1.86$ \\
\hline \multicolumn{3}{|l|}{ flowers $/ \mathrm{m}^{2}$} \\
\hline South Esk R. & $284.0 \pm 62.7$ & $470.4 \pm 95.4$ \\
\hline Tunbridge & $25.0 \pm 25.0$ & $1.8 \pm 1.8$ \\
\hline Campbell Town & $137.5 \pm 44.3$ & $61.9 \pm 28.7$ \\
\hline \multicolumn{3}{|c|}{ percentage cover of grass (Braun-Blanquet + ) } \\
\hline Souch Esk R. & $3.17 \pm 0.16$ & $3.26 \pm 0.18$ \\
\hline Tunbridge & $3.00 \pm 0.38$ & $3.57 \pm 0.37$ \\
\hline Campbell Town & $3.82 \pm 0.23$ & $4.45 \pm 0.34$ \\
\hline \multicolumn{3}{|c|}{ percentage cover of herbs (Braun-Blanquet) } \\
\hline South Esk R. & $4.04 \pm 0.25^{2}$ & $3.91 \pm 0.22$ \\
\hline Tunbridge & $3.86 \pm 0.34$ & $3.71 \pm 0.52$ \\
\hline Campbell Town & $3.55 \pm 0.28$ & $2.27 \pm 0.19$ \\
\hline \multicolumn{3}{|c|}{ percentage cover of bare ground (Braun-Blanquet) } \\
\hline Sourh Esk R. & $3.13 \pm 0.25$ & $3.87 \pm 0.22$ \\
\hline Tunbridge & $1.71 \pm 0.52$ & $1.29 \pm 0.29$ \\
\hline Campbell Town & $3.18 \pm 0.38$ & $2.91 \pm 0.21$ \\
\hline \multicolumn{3}{|c|}{ percentage cover of exotic species (Braun-Blanquet) } \\
\hline South Esk R. & $3.26 \pm 0.20$ & $3.22 \pm 0.21$ \\
\hline Tunbridge & $0.86 \pm 0.34$ & $1.29 \pm 0.18$ \\
\hline Campbell Town & $3.18 \pm 0.18$ & $2.18 \pm 0.23$ \\
\hline
\end{tabular}

$1=<1 \%$ cover, $2=2-5 \%$ cover, $3=6-25 \%$ cover, $4=26-50 \%$ cover, $5=51-75 \%$ cover, $6=76-100 \%$ cover

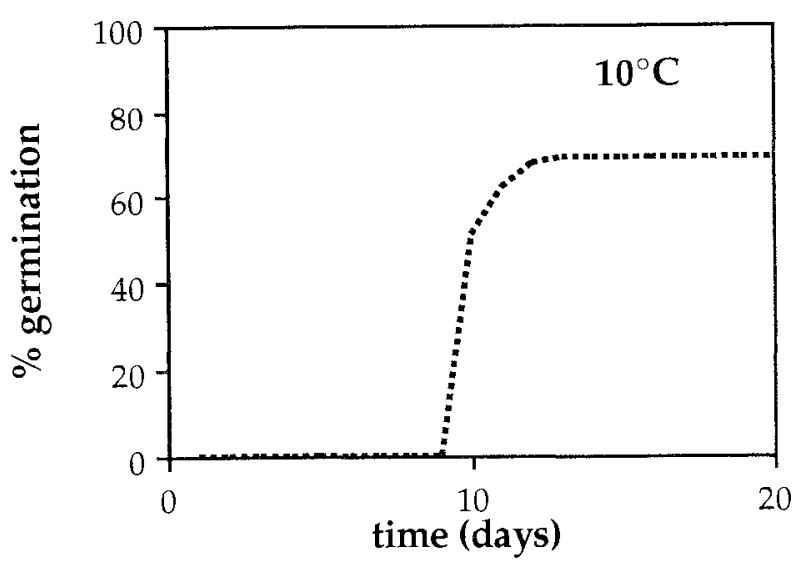

FIG. 2 - Germination curve for Colobanthus curtiseae at $10^{\circ} \mathrm{C}$ extinct (Cropper 1987; Gilfedder 1994). However, these observations also indicate that bare ground may be necessary for its regeneration. Heavy cattle and sheep grazing provide this bare ground through much of its present range, while in some parts of its range, such as the Tunbridge Tiers Stock Route, individuals regenerate in the bare patches associated with tree roots.

The very limited present distribution of the species is almost certainly due to the loss of most of the Tasmanian grassland and grassy woodland on non-rocky soils within its range to improved pasture and cropland (Fensham \& Kirkpatrick 1989). This loss is on-going (Kirkpatrick 1991), so the species deserves to be regarded as endangered, especially given that most of the 16 surviving populations consist of less than 100 individuals.

The major surviving lowland populations of the species need to be protected from pasture improvement and land clearance by mechanisms such as covenanting, management agreements or reservation. Where areas supporting populations have been heavily grazed by stock, it would be prudent to ensure that this form of disturbance continues.

\section{ACKNOWLEDGEMENTS}

We thank Jill Hickie for help with the germination tests and Andrew Zacherek, Fred Duncan, Doug Walsh, Mary Cameron and John Davies for locational records.

This project was supported by grants from the Worldwide Fund for Nature (Australia) and the Endangered Species Program of the Australian Nature Conservation Agency (ANCA).

\section{REFERENCES}

BUCHANAN, A.M. 1995. A CENSUS OF THE VASCULAR PLANTS OF TASMANIA. Tasm. Herb. Occ. Publ. 5.

Busby, J.R., 1988. Porential implications of climatic change on Australia's flora and fauna. In Pearman, G.I. (Ed): GREENHOUSE PLANNING FOR CLIMATE CHANGE. CSIRO, Melbourne.

Croprer, S.C., 1987. Ecological notes and suggestions for conservation of a recently discovered site of Lepidium hyssopifolitum Desv. (Brassicaceae) at Bolwarrah, Victoria, Australia. Biol. Conserv. 41: 269-278.

DAVIES, J.B. \& DAVIES, M., 1989. PLANT COMMUNITIES OF THE BEN LOMOND PLATEAU. Queen Victoria Museum, Launceston.

Endangered Flora Network, 1993. THREATENED AUSTRALIAN FLORA. Australian Nature Conservation Agency, Canberra.

FEnSHAM, R.J., 1989: The pre-European vegetation of the Midlands, Tasmania: a floristic and historical analysis of vegetation patterns. J. Biogeog. 16: 29-54.

FENSHAM, R.J. \& KiRKPATRICK, J.B., 1989. The conservation of original vegetation remnants in the Midlands, Tasmania. Pap. Proc. R. Soc. Tasm. 123: 229-246.

FLora AdVISORY COMMITTEE 1994:NATIVE HIGHER PLANT TAXA WHICH ARE RARE OR THREATENED IN TASMANIA. Parks \& Wildlife Service, Tasmania

GILFEdDER, L., 1994: BARBAREA AUSTRALIS FLORA RECOVERY PLAN: MANAGEMENT PHASE. Wildl. Rep. 94/4. Department of Parks \& Wildlife, Hobart.

Gilfedder, L. \& Kirkpatrick, J.B., 1995. Improving the Conservation of Vegetation Remnants in Tasmania. In Saunders, D., Marriske, E. \& Craig J.L. (Eds): NATURE 
CONSERVATION: THE ROLE OF NETWORKS. Surrey Beatty \& Sons, Chipping Norton, New South Wales.

HILL, M.O., 1979. TWINSPAN: A FORTRAN PROGRAM FOR ARRANGING MULTIVARIATE DATA IN AN ORDERED TWO-WAY TABLE BY CLASSIFICATION OF THE INDIVIDUALS AND ATTRIBUTES. Cornell University, New York.

KIRKPATRICK, J.B., 1991. The magnitude and significance of land clearance in Tasmania in the 1980s. Tasforests 3: 11-14.

KirKpatrick, J.B., GILFEDDER, L. \& FEnSham, R., 1988. CITY PARKS AND CEMETERIES: TASMANIA'S GRASSY HERITAGE. Tasmanian Conservation Trust, Hobart.
MINCHIN, P., 1990: DECODA: Database for Ecological Community Data. Australian national University, Canberra.

Mueller-Dombois, D. \& Ellenberg, H., 1974: AIMS AND METHODS OF VEGETATION ECOLOGY. Wiley International, New York.

WEST, J., 1991. Colobanthus curtiseae (Caryophyllaceae). In Banks, M.R., Smith, S.J., Orchard, A.E. \& Kantvilas, G. (Eds): ASPECTS OF TASMANIAN BOTANY: A TRIBUTE TO WINIFRED CURTIS. Royal Society of Tasmania.

(accepred 14 May 1996) 